UDC $621.397 .13: 621.391 .883$

\title{
10. テレビジョンノイズの主観評価
}

テレビジョン系に和けるノイズの種類は他の通信系と そくに異なるわけではないが，具体的に分類すれば連続 性ノイズ, 周期性ノイズ, およびパルス性ノイズの 3 種 があり，これらのノイズについて，それがテレビ画面に 現われた場合，視覚的にどのように見えるか，あるいは その妨害度はどのように評価されるかについて従来の研 究をまとめてみよう。テレビは最終的に視覚に訴えるも のであるから, 視覚に扣よぼす影響は各種の伝送系の規 格や，サービスエリヤの計画の基本となるものである.

\section{1. テレビにおける連続性ノイズの見え方}

まず基本的には，テレビノイズは空間的および時間的 にランダムに現われるパターンであり，この刺激に詨す る目の基本的な性質から考学るのが正しいのであるが， 十分に説明するだけの資料が不足である. 古くは P. Mertz ${ }^{1)}$ がテレビの連続性ノイズについて，ちょ5ど写 真フィルムの粒状性と同じに考え, 第 1 図のようなモデ ルで四角のアパーチャで走查して得られる出力波形を考 党, 視覚に括けるノイズの実胶的パワーレスポンス $W_{e}$ を

$$
W_{e}=\frac{1}{D} \int_{0}^{\infty} W(f)[\sin \pi f D T / \pi f D T]^{2} d f
$$

とした. ここに $W(f)$ は単位周波数あたりのルミナン スノイズパワー, $D$ は(視距離 $/ 4 \times$ 画面高), $T$ は $D=1$
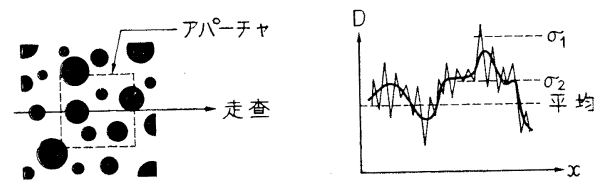

第1図二次元の粒子モデル, 矩形アパーチャで走 査する

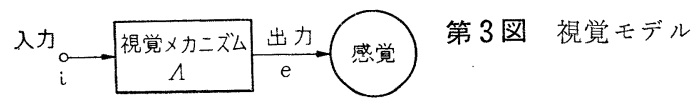

"Subjective Evaluation of Television Noises" by Kenji Hiwatashi

$50(50)$
NHK 技術研究所 樋 渡 涓 二

に抢いてサンプル面積を走査する時間である.（1）式 にもとづいてノイズに対する視感曲線を求めた。また一 方に执いて, 走査した出力のノイズパタンの零レベル交 叉の実効周波数 $f_{e}$ は

$$
f_{e}=\int_{0}^{\infty} f^{2} W(f) d f / \int_{0}^{\infty} W(f) d f
$$

で, かつ $W_{e}=W / k N T D^{2} f_{e}$ (ここに $W$ は実際の全) イズパワー, $k$ は常数, $N$ は画面高の走查線数), $f_{e}=f_{0} /$ $\sqrt{3}, W=f_{0} W(f)$ (ここに $f_{0}$ はノイズの上限周波数） から, $W_{e}=c \sqrt{3} W(f)$.

一方, 平坦特よび三角ノイズについての実験結果と上 記 2 つの近似理論を照合して第 2 図を得た.

ごく最近，オーストラリアの Budrikis ${ }^{2)}$ は第3図の 視覚モデルに䋆て

$$
\begin{gathered}
e(x, y, t)=K \int_{0}^{\infty}\left\{\int \int _ { R } i ( \xi , \nu , t - \tau ) \operatorname { e x p } \left[-\left\{(x-\xi)^{2}\right.\right.\right. \\
\left.\left.\quad+(y-\nu)^{2}\right\}^{1 / 2} / r_{0}\right] d \xi d \nu \times \exp \left[-\tau / t_{0}\right] d \tau
\end{gathered}
$$

ここに $K$ はain const., $r_{0}$ は Characteristic distance, $t_{\theta}$ は時定数で, この 3 常数は間測定によって得 られ，実際は網膜の順応レベル (adaptation level) と， 網膜部位の関数である. 氏はこのモデルで従来の視覚心 理学の Piper, Ricco, Pieron および Bunsen Roscoe の各法則を( 3 )式の近似計算から得られることを示し,

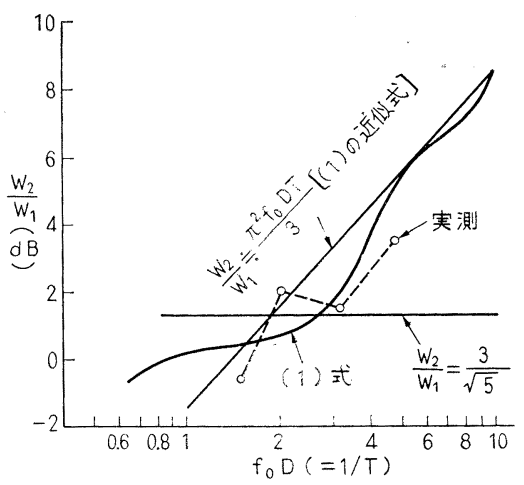

第 2 図 平坦と高域強調ノイズの見え方の相異 $\left(W_{1}, W_{2}\right.$ は乞れぞれ平坦と高域強調ノイズの同一カットオ フ周波数に対する全パワー) 
また Blackwell のコントラスト閾值のデーダ3), Grah$\mathrm{am}$ 等の目の時定数のデーダ4) も説明できるとし，(3) 式のモデルでテレビノイズの評価曲線を説明した。 また 洞時にテレビノイズの視覚に牱ける積分効果や, 走查線 構造についても説明している.

\section{2. 連続性ランダムノイズの周波数に関す る視感評価曲線 (Weighting Curve)}

連続性ランダムノイズの見方方を周波数スペクトル的 視感補正の曲線の測定または擬似回路の提案は, 実用上 の(要求伝送規格制定)から CCIR の研究課題でもめり, きわめて多い. 周波数スペクトルについての視感評価曲 線 $W(\omega)$ の測定は普通白色ノイズ (white noise) を狭 带域のフィルタを通し，そのノイズ画像をラスタ高の 4 倍の距離で適当な輝度で測定する.すなわち $W(\omega)>0$, $0 \leq \omega \leq \Omega$ で, 2 つの電力スペクトル密度 $N_{1}, N_{0}$ は

$$
\int_{0}^{\Omega} W(\omega) N_{1}(\omega) d \omega=\int_{0}^{\Omega} W(\omega) N_{0}(\omega) d \omega
$$

のとき主観的等価値である. いま $N_{i}(i=1 \sim m)$ の異な るノイズスペクトルを作り，これが 0〜 $\Omega$ をガーし， かつ互に独立で $N_{0}$ が近似的汅これらの線形結合で表わ されるよらにえらぶ，そして $N_{k}$ が $N_{0}$ にくらべてひ としく見える $N_{k}$ の電力利得を $1 / y_{k}$ とすれば

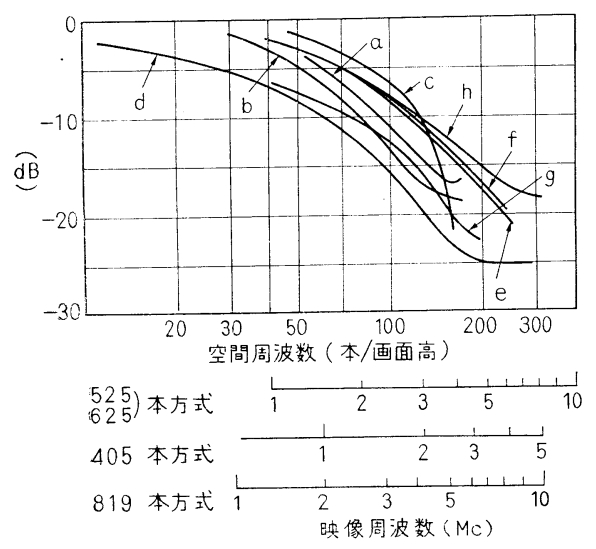

(禋準方式による横軸の換算は水平周波数で行なってある)

[405 本方式]

a : Gilbert, BBC Monograph (1955)

b : Kilvington, J. Television Soc. (1959)

[525 本方式]

c : Mertz, J.SMPTE (1950)

d : Christopher \& Barstow, Trans. AIEE, (1954)

e : Hiwatashi \& Yamaguchi, NHK Tech. J. (1958) [625 本方式]

f : Sennhenn, Flectr. Rdsch. (1959)

g : Mueller \& Demus, MTZ (1959)

[819 本方式]

h : Goussot, londe electrique (1959)

第4図 各国から報告されたテレビ連続ノイズの 評価曲線 (Weighting Curve)

$$
\frac{1}{y_{k}} \int_{0}^{\Omega} N k(\omega) W(\omega) d \omega=\int_{0}^{\Omega} N_{0}(\omega) W(\omega) d \omega(5)
$$

で求める評価曲線は

$$
W(\omega)=\sum_{k=1}^{m} y_{k} G_{k}(\omega)
$$

ここに $G_{k}(\omega)$ は近似的に

$$
\int_{0}^{\Omega} G_{k}(\omega) N_{r}(\omega) d \omega= \begin{cases}0 & r \neq k \\ 1 & r=k\end{cases}
$$

を満足する関数である ${ }^{5)}$ こここに(6)式の線形結合は簡 単のための仮定であって，視覚に和けるマスキングを考 咒れば各帯域の線形結合は, 本当は正しくない。

しかし従来のデータはほとんど（6）式を仮定して特 り, 各国の異なる標準方式で測定され, 提案されてい る6 18)ので, これを水平周波数 $f_{h}$ で換算して同一戝面 に表わしたものが第 4 図である。また，この評価曲線は $1 /\left\{1+\left(f \mid f_{c}\right)^{2}\right\}$ で近似すること(視覚の Spread function を指数形々考光る)は大体みな一致するところであって， 評価曲線の擬似回路として第 5 図のよ $5 な る の^{16)}$ が提案 されている，この評価曲線がきまると，ノイズのスペク トルの形状，たとえば白色抒よび三角ノイズに対する視 覚的に等価なノイズパワーが計算できる.

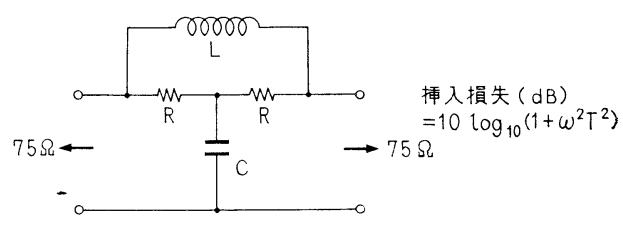

第 5 図 連続ノイズの周波数評価関数擬似回路
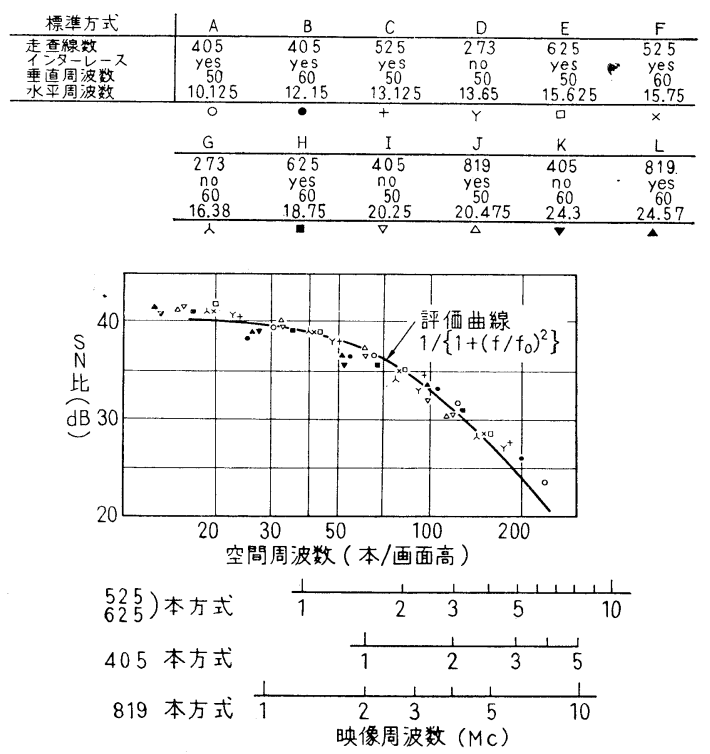

第 6 図 異なる標準方式に対するテレビ連続性 ノイズの評価曲線 


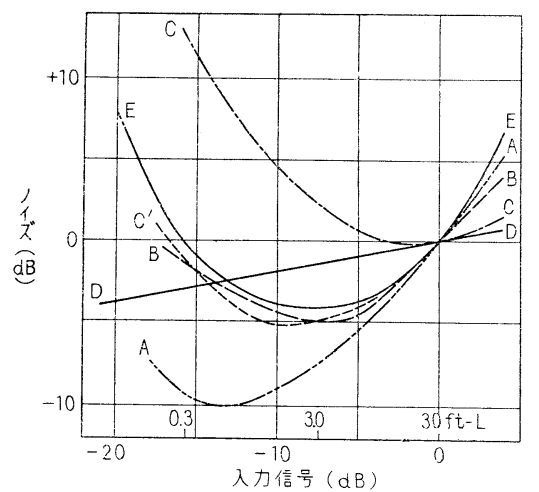

第 7 図信号レベルに対する連続性ノイズの見え方 相対值, $0 \mathrm{~dB}$ は $30 \mathrm{ft}-\mathrm{L}$ 飞対応, 受像機ガンマは 2.5 A : Hecht (1924) B : Shade RCA Rdv (1948) C, C' : Mertz SMPTE (1950)

D : Maurice BBC Mongraph (1955)

E : Hiwalashi \& Yamaguchi

つぎに異なる標準方式間の換算については, やはり CCIR の課題となって和り，山口（NHK）が測定した結 果 $\left.{ }^{19}\right)$ が女る.これは同一ブラウン管, 同一物理条件, 同 一観測者のもとに各方式について評価関数を求めたもの で，その結果は第 6 図に示すように 405 819 本，50 和 よび $60 \mathrm{c} / \mathrm{s}$, インターレース有無の 12 種の方式につい ては $f_{h}$ の換算のみでよく, $f_{v}(50 / 60 \mathrm{c} / \mathrm{s})$ は関係がな いことがわかった(CCIR, 1962, Bad Kreuznach).

\section{3. 連続性ランダムノイズの輝度に対する 視感評価曲線}

つぎにブラウン管輝度に対して見えすがどうであろら か. BBC の Maurice ${ }^{9)}$ 等はテレビ伝送系のノイズのレ ベル分布を計算するさい，画面輝度に対する視感は $1 / 3$ 乗の曲線であり, ちょうどブラウン管の特性（3 乗）と かけ合わせると 1 になるので, ブラウン管グリッドに加 わるノイズが一定ならば輝度レベルに無関係に一定に感 ずるものと仮定した. Budrikis ${ }^{2)}$ 同様炕考えている.

しかし，われわれの穾験では明らかに画面の黒部と白部 とではノイズの見え方が異なり，第 7 図に示すように数 $\mathrm{dB}$ の差がある. さらにこれを輝度 $B$ に対し Fechner fraction $A B / B$ で示すと第 8 図のようである14,18). Hacking ${ }^{20)}$ は Moon と Spencer の古いデータ (中心 視, 1 1.5 の視票, 第 8 図の F, G) 学利用し, Fechner fraction $A B / B$ に対し, ブラウン管の特性 $B-B_{\min }=$

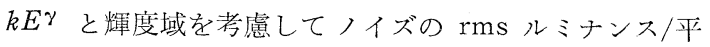
均ルミナンスを $\sigma B / B$ で表わし，かつノイズの見え方 は $\log (\sigma B / \Delta B)$ に比例するとしてこれを輝度 $B / B_{\max }$ に対して求めた（第 9 図). $20 \log (\sigma B / \Delta B)$ は, 単位は “dicilum”である。これによっても明らか比較的暗部
のノイズは明部にくらべて $4 \mathrm{~dB}$ 以上目に感じやすいこ とがわかる。

\section{4. テレビ伝送系と $S \boldsymbol{N}$ 比}

上記のようにブラウン管グリッドに入るノイズが一定 レベルの白色ノイズであっても, 視覚としては 2 種類の Weighting Curveを考えなければならぬ.ささて実際の テレビ伝送系においては，ノイズ源は使用する撮像管に よってノイズスペクトル拈よび信号レベルによるノイズ 振幅を異にし，かつ伝送系に拈いてアパーチャ補正やガ ンマ補正を行なったり，フィルムが介入するとそれらの ノイズ分布が変化し，マイクロ中継やVTRに掠いては FM 後汇混入するノイズは復調後三角ノイズとなるなど で，最終的受像管入力に利けるノイズの性質はかなり複 雑である ${ }^{9,21)}$. したがって $S N$ 比として単に p-p/rmsの 表現は必ずしも画像を観視したときの印象とは異なるで あろう，そこでノイズの分布と視感補正特性をも加味し た SN 比で表示することが望ましい，筆者はとのため スペクトル带域とダイナミックレンジを制限した場合の

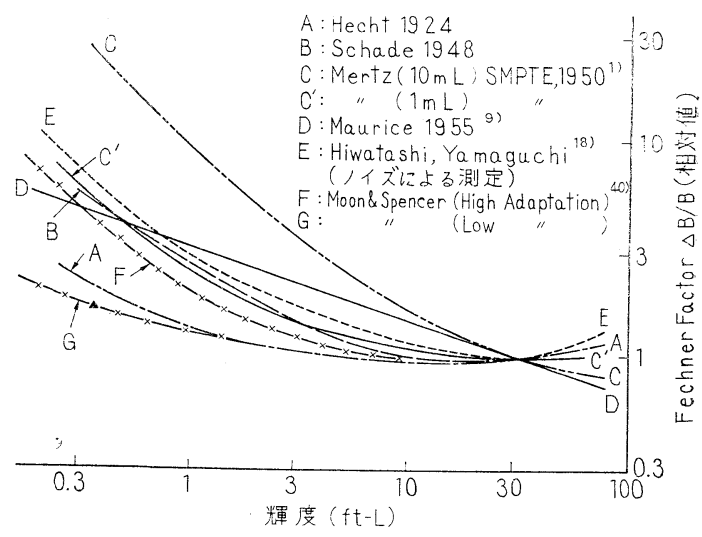

第 8 図 平均輝度に対するFechner Factorを求め たるの（曲線がそれぞれ異なるのは測定に用 いたパターンの相違にもとづく）

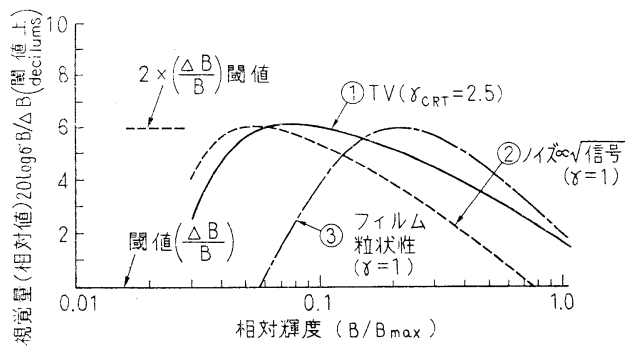

第 9 図 3 種のノイズについて平均輝度に対する見光 方 (K. Hacking)

(1): コントラスト地 $50: 1$. Low Adaptation Threshold, $B_{\max }=10 f_{t}-L$

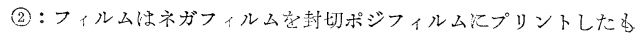
○（ $B_{\max }$ はベー大浿度 +0.2$)$ 


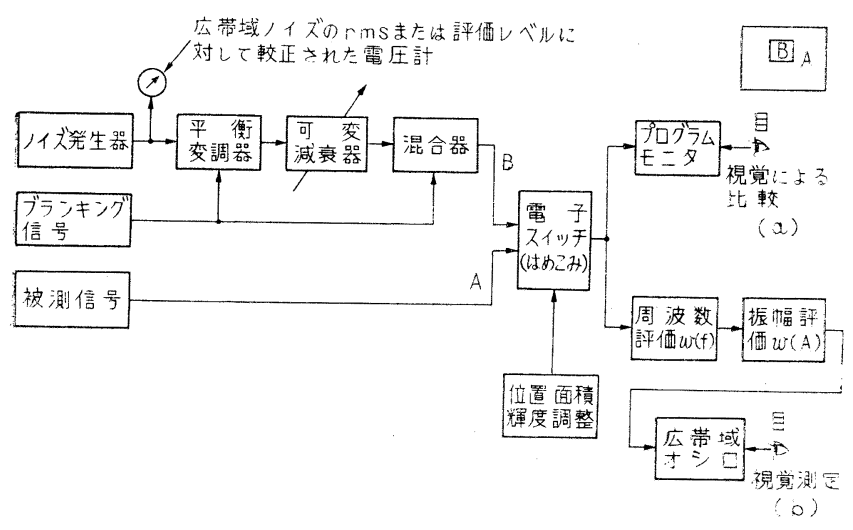

第 2 表 TASOが行なった連続ノイズの 評価

\begin{tabular}{|c|c|c|c|}
\hline & Comment & $S N$ 比 & $50 \%$ 限界值 (dB) \\
\hline $\begin{array}{l}1 . \\
2 . \\
3 . \\
4 . \\
5 . \\
6 .\end{array}$ & $\begin{array}{l}\text { Excellent } \\
\text { Fine } \\
\text { Passable } \\
\text { Marginal } \\
\text { Inferior } \\
\text { Unusable }\end{array}$ & $\begin{array}{l}39 \\
29.5 \\
23.5 \\
19 \\
14\end{array}$ & $\begin{array}{l}(38) \\
(1 /) \\
(24.5) \\
(20) \\
(13)\end{array}$ \\
\hline
\end{tabular}

7 種の Scene の平均値（カッコ内は Miss TASO 種)

(IRE, TASO Issue, June, 1960)

$S N$ 此は第 1 表に同じ

せ第 10 図テレビ評価ノイズ量測定系統図
実効平均ノイズ係数 $\bar{F}_{e w}$ として

$$
\bar{F}_{e w}=\frac{1}{B} \int_{f_{1}}^{f_{2}} \int_{a}^{1} A^{2} \dot{F}_{f} W(f) \dot{F}_{a} W(e) d f d e
$$

そ提案した．ここに $B$ はノイズ等価帯域幅，A は規準 化した信号振幅， $\dot{F}_{f}, \dot{F}_{a}$ はそれぞれ周波数に対する点〉 イズ指数，レベルに対する点ノイズ係数，W(f),W(e) は視感補正曲線である，そして $S N$ 比としては放送の平 均レベル分布を求めて，その Weighting を考㝋て平均 值を出す。また，この測定には標準のノイズを被測定画 面中にはめこんで測定する方法(第10図)を提案した ${ }^{18)}$.

\section{5. 連続性ランダムノイズの評価}

実際のテレビ画面に和けるノイズ量に対し，検知限，

第 1 表 P.Mertz (SMPTE，57，Aug.，1951) による連続ノイズに対する評価

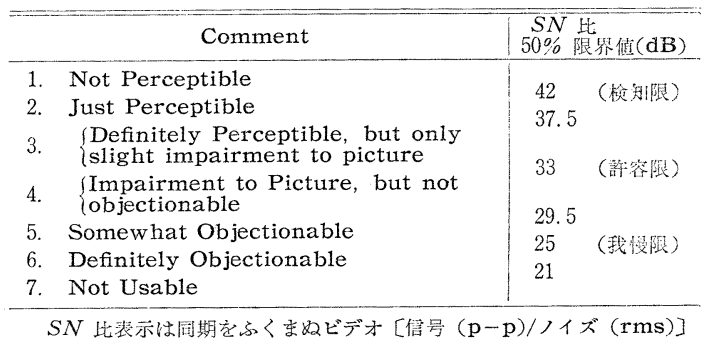

第3表 NHK に打ける連続ノイズ（受信機内 部ノイズ)の評価

\begin{tabular}{|c|c|c|c|c|}
\hline Comment & $\begin{array}{l}\text { テススト } \\
\text { パタン }\end{array}$ & $\begin{array}{l}\text { Kitchen } \\
\text { Gire }\end{array}$ & $\begin{array}{l}\text { Miss } \\
\text { TASC }\end{array}$ & 限界值 \\
\hline $\begin{array}{ll}5 . & \text { 妨害がわからない } \\
4 . & \text { 妨害がわかるが気にならない } \\
3 . & \text { 努害が気になるがじやまにな } \\
& \text { らない } \\
2 . & \text { 妨害がひどくてじやまになる } \\
1 . & \text { 受信不能 }\end{array}$ & \begin{tabular}{|c|}
$\mathrm{dB}^{*}$ \\
$61(39)$ \\
$50(30)$ \\
$38(19.5)$ \\
\end{tabular} & $\begin{array}{c}\mathrm{dB} \\
62(40) \\
51(31) \\
42(23)\end{array}$ & $\begin{array}{l}\mathrm{dB} \\
65(42) \\
56(35) \\
\\
45(26)\end{array}$ & $\begin{array}{l}\text { 検知限 } \\
\text { 許容限 } \\
\text { 我慢限 }\end{array}$ \\
\hline 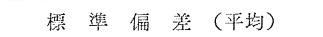 & 6.0 & 4.4 & 5.3 & \\
\hline
\end{tabular}

* 数字は受像機入力電压 $(300 \Omega$ 端子電王) で, $0 \mathrm{~dB}=1 \mu \mathrm{V}$, カッユ内 は $S$ (ペデスタルレバルから 1 信号の白ピークを $\mathrm{p}-\mathrm{p}) / N(\mathrm{rms})$ (dB)

** 評定者はNHK 受信機部職員を主体としたテレビ技術者で，突際と 各地を巡呬し，受信状態を評価している者 10 名.
許容限などを求めることは置局計画などに必要なことで める、一般にこの種の実験は聴視者（母集団）を代表す ると思われる大勢の評定者を集め，いわゆるカテゴリー 法（評定尺度法または段階評価法）によって測定されて いる ${ }^{22)}$.

第1表は Mertz のもの，第 2 表は米国の TASO(Television Allocation Studying Organization) の測定 ${ }^{23)}$ 值であり，第3 表はNHKに打いて測定されたものであ る24)。な叔第 3 表に预いて，4 45 の間 $(50 \%)$ の值を 検知限，4と 3 の間を許容限， 3 と 2 の間を我慢限と称 している。また NHK で個人の巡回員の主観評価の個人 内拉よび個人間凛差をはぶくため, 写真印画による基準 (限度) 見本を作った。これによれば入力電界で $5 \sim 6 \mathrm{~dB}$ の個人誤差を $2 \mathrm{~dB}$ 程度まで減らすことができる.

な和第 1，2，3表加ら一般の画像に対する検知, 許容, 我慢限は $3 \mathrm{Mc}$ 带域（受像機の IF できまる）に対し， それぞれ $S N$ 比で約 $42 \mathrm{~dB}, 33 \mathrm{~dB}, 25 \mathrm{~dB}$ と考えてよ から 5 .

\section{6. 正弦波妨害の見え方}

正弦波妨害の見え炕対する基本的な視覚のデー多は

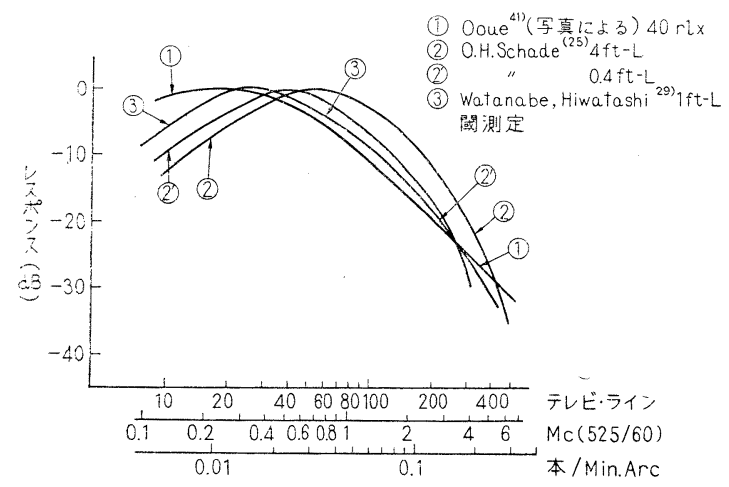

第 11 図テレビジョンに括ける肉眼の空間正弦波 レスポンス 


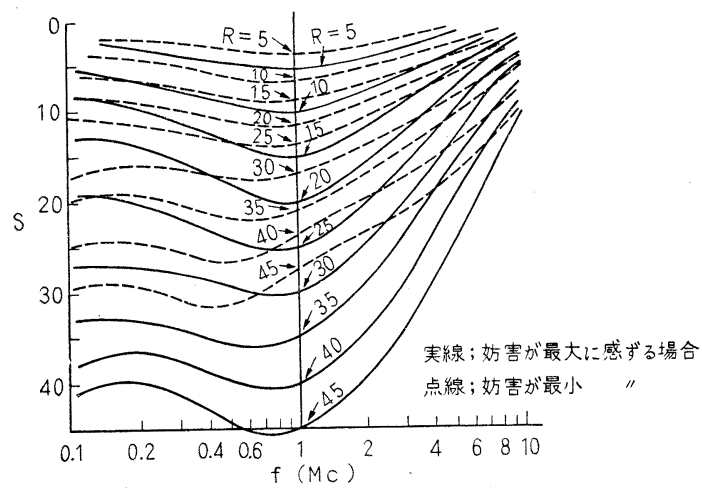

第 12 図 正弦波妨害に対する視覚 (Goussot)

$$
\begin{aligned}
& S=2010 g \frac{\text { 信号 } \mathrm{p}-\mathrm{p} \text { 值 }}{\text { 妨害 } \mathrm{p}-\mathrm{p} \text { 值 }} \\
& R=\text { 管号 } 1 \text { Mc } \text { の妨害正弦波 ( } \mathrm{p}-\mathrm{p} \text { 值) }
\end{aligned}
$$

視覚の空間的正弦波レスポンス関数执よび時間的正弦波 レスポンス関数である. 前者の例としては $\mathrm{Schade}^{25)}$, 大 上26), Lowry $^{27)}$, Goussot ${ }^{30)}$ (第 12 図）特よび NHK 技 研のデータ ${ }^{28,29)}$ (第 11 図) がある.

この特性の高域は平均輝度の高いほど, パタンのコン トラストの高い法ご延び，低域は中域よりやや低下す る.また正弦波パターンが適当な一定速度で移動すれば 中域以下の感度が上昇することが知られている ${ }^{25,26)}$ 。低 域のレスポンス低下は Mach 現象に対応するものであ ろ ${ }^{27)}$. Mach 現象とは急激に白から黒に移る部分が, さらに強調されて見えることをいう。

一方，時間的な変化に対しては矩形波フリッカの融合 周波数 (Critical Fusion Frequency, C.F.F.) について 古典的な 2 つの法則，すなわち Ferry-Porter*の法則と Talbot-Platean** の法則は有名であるが，ここでは時 間的正弦波の各周波数に対する視覚の閾值（threshold）

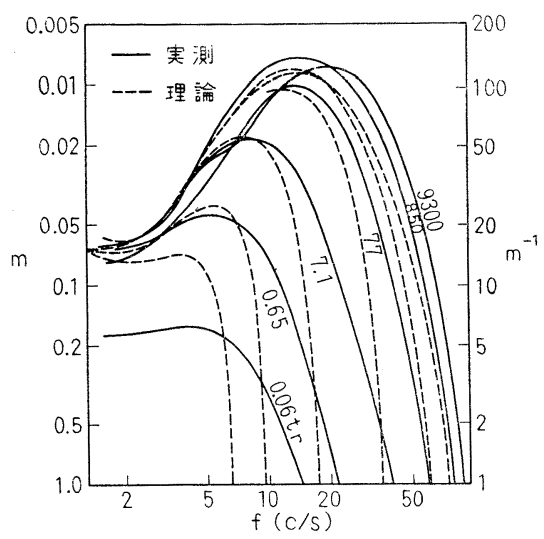

第 13 図 眼の時間的正弦波レスポンス (D. H. Kelly 一個人のもの ${ }^{32)}$ )

[図中 $t_{r}=$ トローラント゚] $f(t)=B(1+m \cos \omega t)$ 飞対する閶値を 求めたもの. $\mathrm{m}^{-1}$ は Amplitude Threshold という.
第4 表 色副搬送波と音声搬送波間ビートに対する

\begin{tabular}{|c|c|c|c|c|}
\hline & 検 & 知 & 許 & 容 \\
\hline $\begin{array}{l}f_{i}=n f h \\
\text { free }\end{array}$ & & & & \\
\hline$f_{i}=(2 n+1) \frac{f h}{2}$ & & & & \\
\hline
\end{tabular}
$3.58 \mathrm{Mc}$ 減哀度 $(\mathrm{dB})$

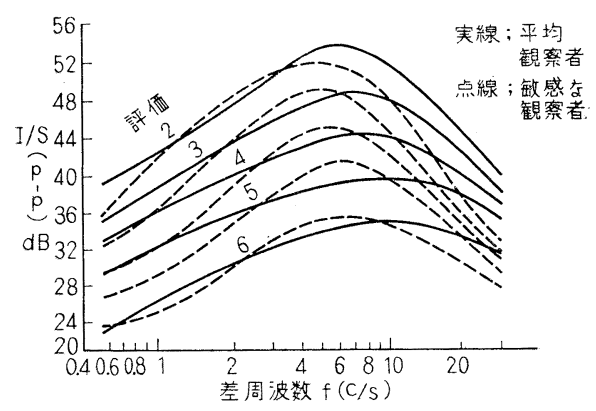

第 14 図 Fowler の正弦波妨害周波数と $60 \mathrm{c} / \mathrm{s}$ ᄀ イールド周波数との差（ $f$ ） に対する妨害 度評価

のデータが基本となる. この基本的な測定は, 最近 Lan$\mathrm{ge}^{31)}$ と Kelly ${ }^{32)}$ (第 13 図) が発表している. いずれも $10 \sim 20 \mathrm{c} / \mathrm{s}$ で感度が上がり，20 c/s 以上では急激に下降 する.これは輝度が高い汪ど極端である。

* C.F.F $\infty \log L(L$ は輝度 $)$

** 融合したときの明るさの感じは輝度变化の平均値である.

\section{7. 正弦波ノイズの主観評価}

前節にのベた視覚の基本特性はテレビジョンに対する ものではない、テレビジョンでは走査線があり，受像面 の残光も字からテレビ受像管で測定したものが実用上

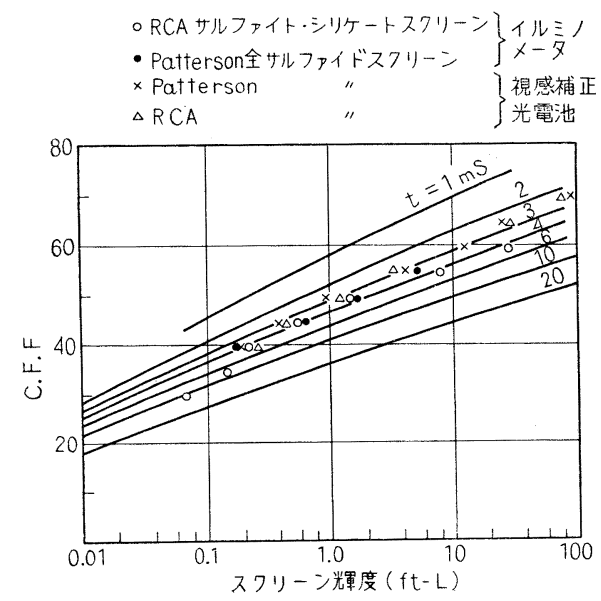

第 15 図 O.H. Schode のテレビに拈けるフリッカ の特性

条件：視距離 $\rho=4 \sim 5$, スクリーンの大きさ 4.5 吋 $\times 6$ 吋中心鿆 インターレースなし，暗室， $t=5 \%$ までの残光時間 


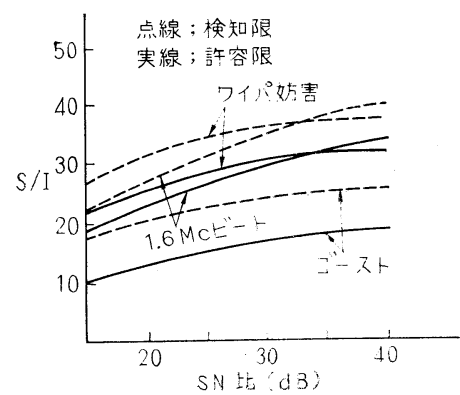

隣接于ャ文分妨害

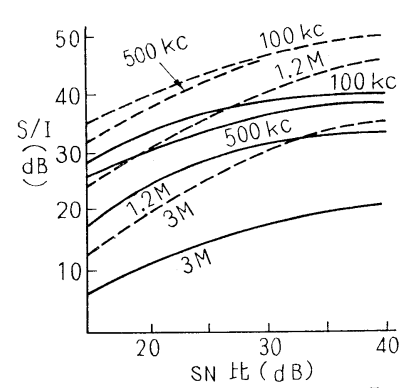

単一周波数妨害(調整法, $5 \mathrm{H}, 20$ 名) $50 \%$ 值

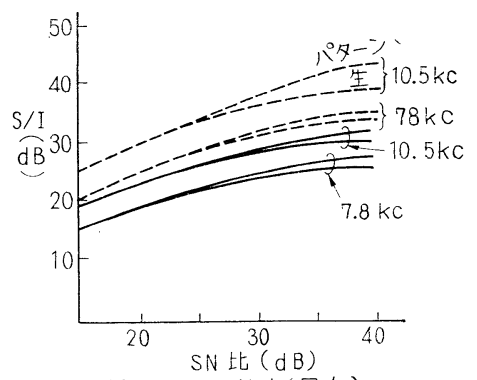

同一チャネル妨害(同左)

第 16 図受像入力 $\left(S N\right.$ 比) 飞対する各種好害 ${ }^{35)}$ ( NHK 技研石橋他)

望ましい, ハム妨害の評価については, Fowler のデー タ33)がある.すなおち妨害信号周波数と $60 \mathrm{c} / \mathrm{s}$ フィー ルド周波数との差のフリッカ周波数に対し， 6 段階評価 を行なったもので， $5 \sim 7 \mathrm{c} / \mathrm{s}$ の差周波数に最も敏感であ る(第 14 図)。また Schade は25)テレビ画像でその残光 時間をパラメータにして, Ferry-Poter の法則を示す測 定を行なった（第 15 図）.

妨害の周波数が高くなると画面上倕摇する縞模様と なって現われるが，前記空間周波数レスポンスがこれに 対応する. 実用上のデータとしては, 同一周波放送のた めのオフセット方式関する Kell のデータ ${ }^{34)}$ は有名で 女るが，同一および上下隣接チャネルの妨害を段階評価 した TASO の詳しいデータがある23).

カラーテレビをはじめるにあたり，調査会が電波審議 委員会に設けられ，その答申のためいくつかのデータが 主としてNHK で測定された. 第 1 飞石橋, 他の測定に よれば輝度信号と色信号との漏話 $(2.1 \sim 4.2 \mathrm{Mc})$ につ いて，副搬送波ドットは $3.58 \mathrm{Mc} ト$ トップを插入し，

第 5 表 パルスノイズ評価の一例 (NHK) [評定者は第 4 表と同一]

\begin{tabular}{|c|c|c|c|c|}
\hline \multirow{2}{*}{ 評 価 } & \multicolumn{2}{|c|}{ テストパターン } & \multicolumn{2}{|c|}{ Kitchen Girl } \\
\hline & $D^{*} * 40 \mathrm{~dB}$ & $50 \mathrm{~dB}$ & $40 \mathrm{~dB}$ & $50 \mathrm{~dB}$ \\
\hline & $26.8^{* *}(11.0)$ & $43.1(9.3)$ & $35.1(10.4)$ & $47.5(5.2)$ \\
\hline 許 容 限 & 21. $0(16.3)$ & 17.0(11.7) & 8. $6(15.7)$ & 21. 8(14.3) \\
\hline 我 慢 限 & $-18.9(5.0)$ & $-6.5(4.9)$ & $-13.1(7.6)$ & $-2.1(7.0)$ \\
\hline
\end{tabular}

* 希望信号レベル, $300 \Omega$ 負荷入力電压 $(1 \mu \mathrm{V}=0 \mathrm{~dB})$

** 電波審議会規格雑音強度測定器準尖頭值で測った $300 \Omega$ 負荷入力電 圧

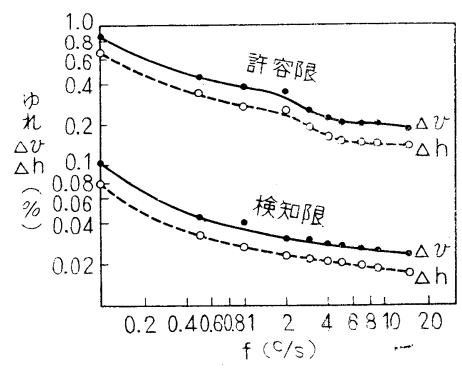

第 17 図 テレビ のラスタゆれ の検知, 許容 限 ${ }^{36)}$ (石橋他)

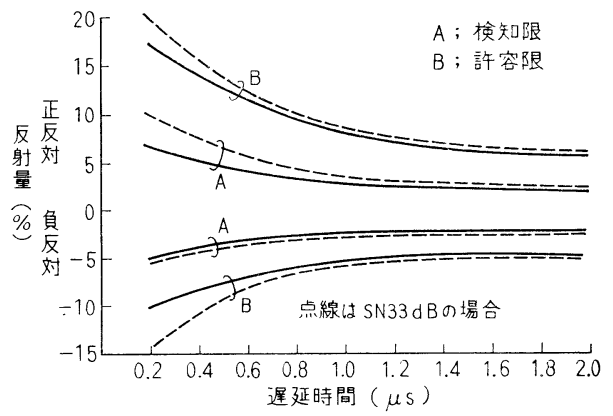

第 18 図 反対像の評価 (石橋他). モノスュープ (テストパターン), 視距離 $4 \mathrm{~h}$

許容值は $3.58 \mathrm{Mc}$ 減衰度 $6 \sim 10 \mathrm{~dB}$ でめり, 色副搬送波 と音声搬送波間 $920 \mathrm{kc}$ ビートは第 4 表に示す ${ }^{35)}$. 第 2 に受像入力に対する同一扔よび隣接チャネル妨害の検知 および許容限を測定した（第 16 図）.

\section{8. パルスノイズの主観評価}

自動車点火栓ノイズや，ビデオテープのドロップアウ トのようなパルス性ノイズの見光方はきわめて複雑な要 素をふくんでいる. 継時的な刺激に対する視覚について は前後の刺激が干渉するし, 刺激のあとの視覚の残像は かなり複雑な様相を呈することがわかっている，パルス ノイズの場合, その数の印象は実際の数と直線的ではな く，その発生頻度とパルスのパタンの長さによってかな り異なる ${ }^{24)}$.

またパルスノイズを多くの評定者に主観評価せしめる と, ノイズの発生頻度が増すほど評価がばらつく，実際 に自動車点火栓ノイズについて発生頻度を $250 \mathrm{c} / \mathrm{s}$ とし た場合, 受像機の電界入力（端子電圧 $300 \Omega, 1 \mu \mathrm{V}=$ $0 \mathrm{~dB})$ に対するパルスノイズの評価は第 5 表に示すよ 5 である。な敃第 5 表は評定者の母集団の性質の異なる場 合の実験 ${ }^{37)}$ と約 $10 \mathrm{~dB}$ の開きがある.

(49 頁へ続く) 
を白黒テレビ信号度程にすることによって，カラーテレ ビ画像の解像度と $S N$ 比を向上させるものである. 色度 情報用撮像管のノイズは主として再現画像の色度ノイズ になり，なた輝度信号の $3.58 \mathrm{Mc}$ 近傍ノイズによるク口 ミナンスノイズが減少するため, カラ一画像のノイズ特 性が大幅に改善される。3 年 5 月，NHK 技研に沶いて 色度用として 3 时 IO 3 本, 輝度用として 4.5 时 IO を 用い撮像実験を公開したが，色度用10 の入射光量が減 ってSN 比が約 $1 / 5$ に低下しても, 再現画像のノイズは 通常の $3 \mathrm{IO}$ カメラの場合と同等に保たれることが示さ れた。

\section{5.むむび}

クロミナンスノイズの再現画像に及ぼす影響が, 輝度 ノイズにくらべ無視できないことがわかった，とくにフ リンジェリアで問題である2).

カラーテレビのノイズに関しては, 現在のところ視覚 試験の資料が不十分で，たとえば NTSC 信号のノイズ 評価曲線にしてもな渗検討の必要があろう。色度ノイズ
に対する評価曲線, 輝度ノイズと色度ノイズ, 岕るいは 色度の違ら色度ノイズ相互の視覚における相関性など調 査すべきことが多く残されている.

\section{[参考文 献]}

1) W.F.Bailey: The Constant Luminance Principle in NTSC Color Television, Proc. IRE, 42 (1954) 60

2) R.D.A. Maurice: A Review of Colour Television in the U.K., Electronic Engineering, Feb., (1960) 68

3) ベ・エム・ペブズネル：カラーテレビジョン伝送チャネルの相対 效率々雑音安定度 : Техника кино и телевидения, 1959, No. 10.

4) A.V.Lord: Fluctuation Noise in Two Forms of the N.T.S.C. Colour Television System, Journal Brit IRE, April (1962) 322

5) J.M.Barstow : Intercity $\mathrm{B}-\mathrm{W}$ and color television transmission, Bell Telephone System Technical Publications Monograph 2466.

6) ベ・エム・ペブズネル：直角サブキャリヤ夜調カラーテレビの解 音安定度, Техника кино и телевидения, 1961, № 7

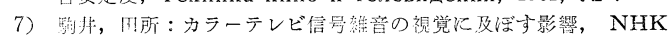
技術研究，12，(1960）393

8) I. J.P.James: Fluctuation Noise in Television Camera Head Amplifier P.I.E.E., Part IIIA, (1952) 706

9）坂井：ビジコン用トランジス夕前置增幅器, 信学会全国大会予稿 594 (1962)

10）林：分離腪度カラー撮像方式，信学会全国大会予稿 (1962) 598

\section{（55 頁より続く）}

\section{9. むす び}

以上のベたほかに，ノイズといえるかどらかは別とし て画面の上下左右の動摇, 反射像などがある、画面動摇 についてはデータが少なく, 石橋らがゆれの周波数注 する検知，許容限を測定したものがある ${ }^{36)}$ (第 17 図). 反射像については Müller ${ }^{38)}$, Fowler と Christopher ${ }^{39)}$, 石橋と白鳥の測定 ${ }^{36)}$ (第 18 図) がある.

最後に本文を草するにあたり多くのデータを参照させ ていただいた各研究者に深謝する.

\section{[参考文献]}

1) Mrtz P : SMPTE, 54, (1950), 8-34.

2) Budrikis, Z.L : Proc. IRE Australia, Dec., (1961). 751759.

3) Blackwell H.R: JOSA, 36, (1946), 624-643.

4) Graham C.H., Margaria R: Amer. J.Physiol., 113, (1935), 299-305.

5) Brainard R.C : IRE Trans., IT-8, No. 2, (1962) 99-106.

6) Christopher H.N \& Barstow, J.N : Trans, AIEE, 73, pt-1, (1954) 735-741.

7) Cuban Telephone Co., Annex 1 to Q 14, 3 rd S. G., 17 th Plenary Assembly CCIF, Geneva, (1954).

8) Kilvington T., et al : P.O. Radio Rep., No. 2289, (1954)

9) Maurice R.D.A, et al : BBC Eng. Monograph, No. 3. (1955). Annex III to Rep. 84, 8 th Plenary Assembly CCIR, Warsaw.(1956). CCITT, Red Book, 1, (1956).

10) Sennhenn E: Elektron. Rdsch., 11, (1957), 271-274 和上 び 13, (1959), 9-12.

11) Maarleveld F: Rep. Nc. 107. R. L. of Dutch PTT, 1957.

12) Netherlands, Doc 12. Annex IV, CMTT Paris. (1957). Doc. 10, Appendix 4, CCIF, (1957). Doc. 9, CMTT, Monte Carlo, (1958).
13) USSR, Doc. 23, CMTT, Monte Carlo (1958), 敊ょび Doc. XI/23, 24, 30, CCIR Moscow (1958).

14) Japan, Doc. 31, CMTT, Monte Carlo(1958) 拈よび Doc. 39, 41, 9 th Plenary Assem. CCIR, Los Angeles(1959).

15) Mueller. J \& Demus, E : NTZ, (1959), 181-186.

16) Kilvington. T: Jour. TV Soc., 9, 26-31(1959).

17) Weaver L. E: Electron \& Radio Eng., (1959) 170-179,

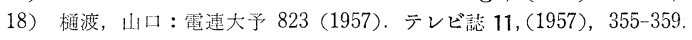
NHK 技研, 10, (1958), 260-266.

19) Japan, Doc. XI, CCIR, Badkreuznach, (1962). 山口: : 通大 (1962).

20) Hacking $\mathrm{K}:$ Jour. Brit. IRE, April, (1962), 307-310.

21）樋派：テレビ誌 16，8，(1962)，456〜461.

22) Mertz P: SMPTE, 57, Ang., 89-107, (1951).

23) Fredendall G. L., et a1: June, 1030 1034, Dean C.E: June, 1035 45, IRE TASO Issue.

24) 檤㴼, 渡部, 钺田: 通大, (1962).

25) Schade O.H : RCA Rev, (1948), 5-37, JOSA 46, 9, (1956) 721.

26) 大上: Jour, App1. Phys., 28, (1959) 531.

27) Lowry E.M \& De Palma, J. J : JOSA, 51, 7, (1961)

28）㛚涭，山口：通大，(1958)，502.

29) 渡部, 他: 通大, (1962).

30) Goussot L : Londe elecirique, 39, (1959) 352-361, 690-700

31) de Lange $H:$ JOSA, 48, (1958), 777-789.

32) Kelly D.H: JOSA, : 51, 4, 422-429. 51, 7, (1961), 747-754. 52, 1, (1962), 89-95.

33) Fowler A. D:IRE, 39, (1951) 1332 1336.

34) Fink D.G: Television Eng. Handbook, Maple Press Co., (1957), 1-15.

35) 石祜, 他 : 電連大予, 347 (1958).

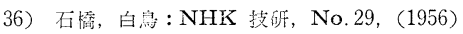

37）鈴木：テレビ辣, 16, 10, (1962) 593〜598.

38) Müller, J:FTZ, 7, July, (1953) 20.

39) Fowler A.D \& Christopher H.N: SMPTE, 58, June, (1952).

40) Moon P. and Spencer D.E: JOSA, 35, March (1945), 233-248.

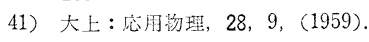

